C. B. Michielse $\cdot$ K. Salim · P. Ragas $\cdot$ A. F. J. Ram

B. Kudla $\cdot$ B. Jarry $\cdot$ P. J. Punt

C. A. M. J. J. van den Hondel

\title{
Development of a system for integrative and stable transformation of the zygomycete Rhizopus oryzae by Agrobacterium-mediated DNA transfer
}

Published online: 15 May 2004

(C) Springer-Verlag 2004

\section{Mol Genet Genomics (2004) 271:499-510}

Owing to a technical error, the legend to Fig. 1 was omitted. The figure and the legend now appear below.
The online version of the original article can be found at http:// dx.doi.org/10.1007/s00438-004-1003-y

C. B. Michielse $(\bowtie) \cdot$ A. F. J. Ram · C. A. M. J. J. van den Hondel Fungal Genetics Group, Clusius Laboratory,

Institute of Biology, Leiden University,

Wassenaarseweg 64, 2333 AL Leiden, The Netherlands

E-mail: Michielse@rulbim.leidenuniv.nl

Tel.: +31-71-5274861

Fax: + 31-71-5274999

K. Salim · B. Kudla $\cdot$ B. Jarry

Orsan, 46 Route de Nesle, 80190 Mesnil Saint Nicaise, France

C. B. Michielse 'P. Ragas · A. F. J. Ram - P. J. Punt

C. A. M. J. J. van den Hondel

Department of Microbiology, TNO Nutrition,

Utrechtseweg 48, 3700 AJ Zeist, The Netherlands

Present address: K. Salim

24 Résidence le Bois du Roi, 91940 Les Ulis, France

Present address: P. Ragas

Molecular Microbial Ecology Group, BioCentrum-DTU,

Technical University of Denmark, 2800 Lyngby, Denmark

Present address: B. Kudla

52 Rue de Gometz, 91970 Les Moulieres, France

Present address: B. Jarry

Tate and Lyle/Amylum N.V., Burchtstraat 10, 9300 Aalst, Belgium
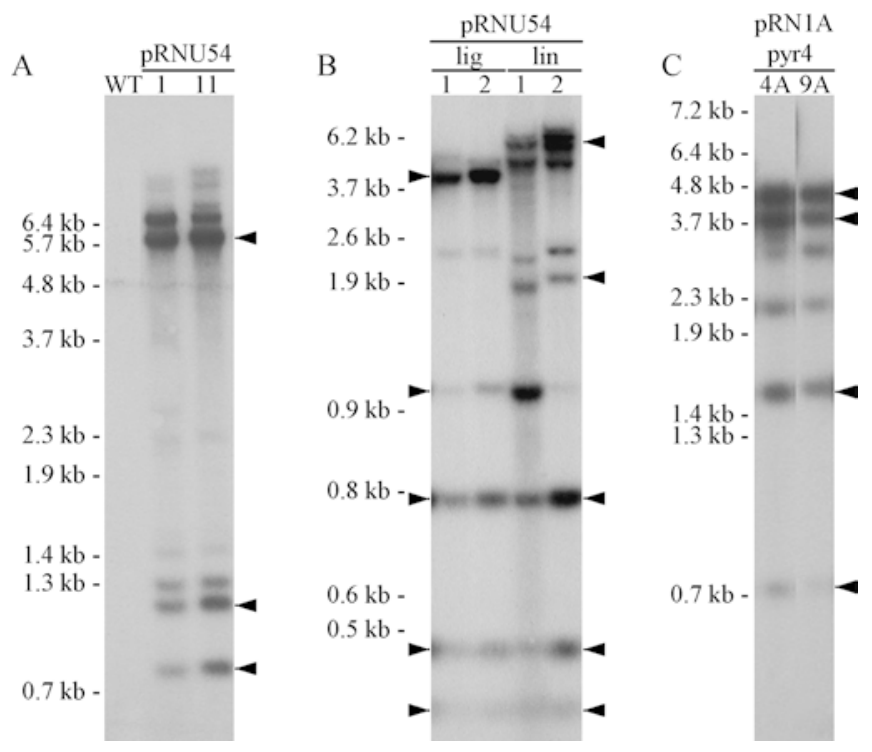

Fig. 1 A-C Analysis of transformants by Southern hybridization. A Southern analysis of [pRNU54] transformants. Chromosomal DNA was digested with EcoRI and probed with pRNU54. WT, undigested chromosomal DNA of COM1247. The arrowheads indicate the expected fragments. B Southern analysis of [pRNU54fragment] transformants. Chromosomal DNA was digested with EcoRI and probed with the 5.6-kb SphI fragment of pRNU54. Transformants obtained after introduction of the linear $5.6-\mathrm{kb}$ $S p h \mathrm{I}$ fragment of pRNU54, corresponding to the pyr4 marker, are designated as lin. Transformants obtained after introduction of the $S p h \mathrm{I}$ fragment pre-treated with DNA-ligase are designated as lig. The arrowheads indicate the expected fragments. C Southern analysis of [pRN1A pyr4] transformants ([pRN1A pyr4]\#4A and [pRN1A pyr4]\#9A), which were able to grow on minimal medium lacking uridine and on acetamide as the sole nitrogen source. Chromosomal DNA was digested with BamHI and probed with pRN1A pyr4. The arrowheads indicate the expected fragments 